\title{
Arbuscular Mycorrhizal Fungi Associated with Rice (Oryza sativa L.) in Ghana: Effect of Regional Locations and Soil Factors on Diversity and Community Assembly
}

\author{
Elsie Sarkodee-Addo ${ }^{1}$, Michiko Yasuda ${ }^{2}$, Chol Gyu Lee ${ }^{3}{ }^{1}$, Makoto Kanasugi ${ }^{3}$, \\ Yoshiharu Fujii ${ }^{2}{ }^{\mathbb{D}}$, Richard Ansong Omari ${ }^{4,5}$, Samuel Oppong Abebrese ${ }^{6}{ }^{\mathbb{D}}$, Ralph Bam ${ }^{7}$, \\ Stella Asuming-Brempong ${ }^{8}$, Khondoker Mohammad Golam Dastogeer ${ }^{2,9}$ (D) and \\ Shin Okazaki ${ }^{2, *(D)}$ \\ 1 United Graduate School of Agricultural Science, Tokyo University of Agriculture and Technology, \\ Saiwaicho 3-5-8, Fuchu, Tokyo 183-8509, Japan; elsieaddo67@yahoo.com \\ 2 Institute of Agriculture, Tokyo University of Agriculture and Technology, Saiwaicho 3-5-8, Fuchu, \\ Tokyo 183-8509, Japan; tosaka.michiko@gmail.com (M.Y.); yfujii@cc.tuat.ac.jp (Y.F.); \\ dastogeer.ppath@bau.edu.bd (K.M.G.D.) \\ 3 Graduate School of Bio-Applications and Systems Engineering, Tokyo University of Agriculture and Technology, \\ Nakacho 2-24-16, Koganei, Tokyo 184-8588, Japan; cglee@go.tuat.ac.jp (C.G.L.); mk.wtfw@gmail.com (M.K.) \\ 4 Institute of Agriculture and Horticulture, Faculty of Life Science, Humboldt-University of Berlin, \\ Albrecht-Thaer-Weg 5, 14195 Berlin, Germany; talk2jafakingonline@gmail.com \\ 5 Leibniz Centre for Agricultural Landscape Research, Institute of Land Use Systems, Eberswalder Str. 84, \\ 15374 Müencheberg, Germany \\ 6 CSIR-Savanna Agricultural Research Institute, P.O. Box 52 Tamale, Ghana; sam555oppa@yahoo.com \\ 7 CSIR-Crops Research Institute, P.O. Box 3785 Kumasi, Ghana; ralphbam@yahoo.com \\ 8 Department of Soil Science, University of Ghana, Legon, P.O. Box LG 245 Accra, Ghana; \\ sasuming-brempong@ug.edu.gh \\ 9 Department of Plant Pathology, Bangladesh Agricultural University, Mymensingh 2202, Bangladesh \\ * Correspondence: sokazaki@cc.tuat.ac.jp; Tel.: +81-42-367-5847
}

Received: 20 February 2020; Accepted: 9 April 2020; Published: 12 April 2020

\begin{abstract}
Understanding the community composition and diversity of arbuscular mycorrhizal fungi (AMF) in an agricultural ecosystem is important for exploiting their potential in sustainable crop production. In this study, we described the genetic diversity and community structure of indigenous AMF in rain-fed rice cultivars across six different regions in Ghana. The morphological and molecular analyses revealed a total of 15 different AMF genera isolated from rice roots. Rhizophagus and Glomus were observed to be predominant in all regions except the Ashanti region, which was dominated by the genera Scutellospora and Acaulospora. A comparison of AMF diversity among the agroecological zones revealed that Guinea Savannah had the highest diversity. Permutational Multivariate Analysis of Variance (PERMANOVA) analysis indicated that the available phosphorus (AP) in the soil was the principal determining factor for shaping the AMF community structure $(p<0.05)$. We report, for the first time, AMF diversity and community structure in rice roots and how communities are affected by the chemical properties of soil from different locations in Ghana.
\end{abstract}

Keywords: arbuscular mycorrhizal fungi; community composition; agroecological zones; phosphorus; rice cultivar; denaturing gradient gel electrophoresis; Illumina MiSeq sequencing 


\section{Introduction}

Rice (Oryza sativa L.) is an important staple food crop in the world that fulfills the needs of over 3.5 billion people by providing over $20 \%$ of their dietary calories [1]. It is considered to be the second most significant source of calorie intake after maize in Ghana. Considering a shift in consumer preference and increase in population growth, the demand for rice is anticipated to continue increasing substantially [2-4]. Currently, local production of rice fulfills less than $40 \%$ of the national consumption, with the population relying heavily on imports at an estimated US\$500 million annually [5-7].

The yield of rice production in Ghana was reported to be low (about $2 t / h a$ ) [8] due to several factors similar to the entire Sub-Sharan Africa [9-11]. Inadequate soil nutrient resulting from poor soil fertility management and inefficient fertilizer application by farmers was reported as one of the major factors affecting rice production [12-14]. Rice is cultivated in Ghana frequently under rain-fed conditions and productivity under this condition has become more difficult due to adverse conditions caused by the constant changes in rainfall patterns, such as drought $[15,16]$ and inappropriate control of water. To boost domestic production of rice, these challenges must be addressed properly. Exploiting indigenous natural resources to enhance and sustain local rice production is crucial. The roles of soil microorganisms in improving soil fertility and crop productivity are well documented. For instance, soil microbes are involved in nutrient cycling and nutrient availability for plants [17-21].

Arbuscular mycorrhizal fungi (AMF), belonging to the phylum Glomeromycota, are part of the soil microbial community that contributes substantially to crop productivity and ecosystem sustainability [22,23]. AMF form beneficial symbiotic associations with the majority of vascular plant species $[24,25]$ and are known to offer numerous benefits to plants, including enhanced nutrient availability to plants and their uptake (particularly P), increased water uptake [26,27], improved biotic and abiotic stress tolerance, and improved soil structure [28-30], thus significantly contributing to the agroecosystem [31,32].

AMF identity and diversity and their effects on plant ecophysiology are influenced by various factors, such as host genotype and growth stage, AMF species, and environmental conditions [33-36]. Therefore, identification of AMF species and exploring their community composition is an important primary step in evaluating their beneficial functional potentials to the host plant. There are many available reports on AMF colonization in several crops, including rice in the temperate regions, and as many as 240 species of AMF were classified [37-40]. However, to the best of our knowledge, no research exists regarding the diversity and community composition of AMF in arable crops, particularly in the rice production system in Ghana.

In several studies, the occurrence of AMF colonization in rice roots under different production regimes at diverse geographical locations demonstrated variable effects on the community compositions of AMF [26,41-43]. Lumini et al. [44] reported that AMF colonization in rice roots occurred only under dry conditions and not in the conventional paddy wet fields. Moreover, Barber et al. [45] demonstrated that farm management practices in rice cultivation significantly influenced the diversity and community structure of AMF. Meanwhile, in Ghana, rice is cultivated in all ten regions under different agroecological zones, characterized by variable climatic conditions and soil nutritional levels. Therefore, we hypothesized that distinct differences remain in the diversity and community composition of the native AMF population in rice grown in different agroecological zones in Ghana. Consequently, the present study aimed to identify AMF associated with rice in Ghana and to characterize the community composition of AMF naturally present in cultivated rice fields in Ghana, relating their structure to prevailing soil conditions in these regions.

\section{Results}

\subsection{Soil Chemical Properties of Rice Fields Varied among Agroecological Zones in Ghana}

In the six regions, a total of 57 rice roots and 57 soil samples were collected (Figure 1). We observed significant variations in several soil properties among the sampled regions (Table 1). All the rice fields 
had an acidic soil $\mathrm{pH}$ (4.9-5.2), irrespective of the region. No substantial differences were observed for soil moisture content $(10 \%-18 \%)$ or carbon-to-nitrogen ratio $(\mathrm{C} / \mathrm{N})$ ratio (Table 1$)$ among the sampled regions. Although the total nitrogen (TN) content was similar in all locations, the concentration of nitrate $\left(\mathrm{NO}_{3}{ }^{-}\right)$in Deciduous Forest zones (DFZ) was approximately 2.4 times higher than the Guinea Savannah zone (GSZ). Interestingly, a similar pattern was observed for ammonia $\left(\mathrm{NH}_{4}{ }^{+}\right)$content (approximately 2 times), available phosphorus (AP) content (approximately 3 times), cation exchange capacity (CEC) (approximately 2 times), and total carbon (TC) (approximately 2.3 times) in DFZ soil compared to GSZ (Table 1).

(a)

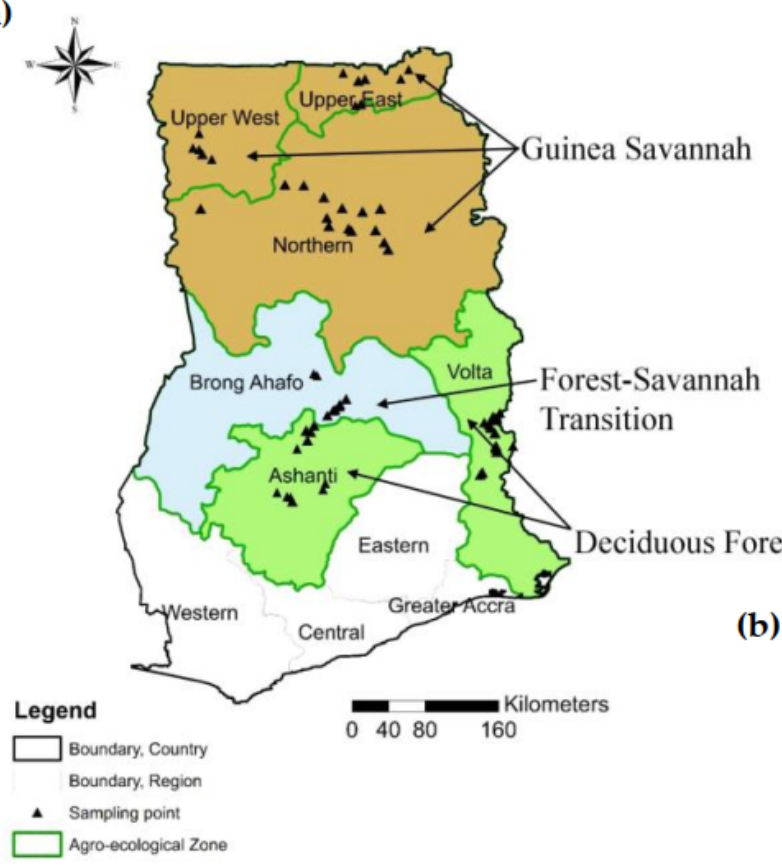

\begin{tabular}{|l|l|}
\hline Sampling region & Latitude /Longitude \\
\hline 1. Upper West & $010^{\circ} 19^{\prime} 599^{\prime} \mathrm{N} / 002^{\circ} 15^{\prime} 00^{\prime \prime} \mathrm{W}$ \\
\hline 2. Upper East & $010^{\circ} 45^{\prime} 00^{\prime} \mathrm{N} / 000^{\circ} 45^{\prime} 00^{\prime} \mathrm{E}$ \\
\hline 3. Northern & $009^{\circ} 30^{\prime} 00^{\prime} \mathrm{N} / 001^{\circ} 00^{\prime} 00^{\prime} \mathrm{W}$ \\
\hline 4. Brong-Ahafo & $007^{\circ} 45^{\prime} 00^{\prime} \mathrm{N} / 001^{\circ} 30^{\prime} 00$ 'W \\
\hline 5. Ashanti & $006^{\circ} 45^{\prime} 00^{\prime} \mathrm{N} / 001^{\circ} 30^{\prime} 00^{\prime} \mathrm{W}$ \\
\hline 6. Volta & $007^{\circ} 00^{\prime} 00^{\prime} \mathrm{N} / 000^{\circ} 30^{\prime} 00^{\prime} \mathrm{E}$ \\
\hline
\end{tabular}

(b)

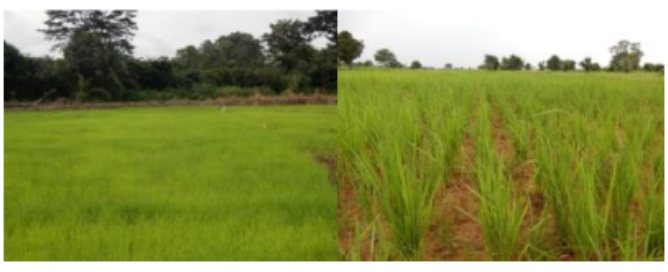

Sampled rice field

Figure 1. Sampling sites in rice-cultivated fields of Ghana with the study area colored in three different colors. (a) The map shows 57 sampling areas marked with black triangles among six different regions under three agroecological zones of Ghana. (b) Pictures of rice fields in Ghana where samples were collected. 
Table 1. Chemical properties of soil samples from six different regions under three agroecological zones in Ghana.

\begin{tabular}{|c|c|c|c|c|c|c|c|c|c|c|}
\hline $\begin{array}{l}\text { Agroecological } \\
\text { Zone }\end{array}$ & Region & $\begin{array}{l}\text { Soil pH } \\
\text { (water) }\end{array}$ & $\begin{array}{c}\text { Soil } \\
\text { Moisture } \\
\text { Content (\%) }\end{array}$ & $\begin{array}{c}\text { Total } \\
\text { Carbon } \\
\text { (g/kg) }\end{array}$ & $\begin{array}{c}\text { Total } \\
\text { Nitrogen } \\
(\mathrm{g} / \mathrm{kg})\end{array}$ & $\mathrm{C} / \mathrm{N}$ & $\begin{array}{c}\mathrm{NH}_{4}{ }^{+} \\
(\mathrm{mg} / \mathrm{kg})\end{array}$ & $\begin{array}{c}\mathrm{NO}_{3}^{-} \\
(\mathrm{mg} / \mathrm{kg})\end{array}$ & $\mathrm{AP}(\mathrm{mg} / \mathrm{kg})$ & $\begin{array}{c}\mathrm{CEC} \\
\left(\mathrm{cmol}_{\mathrm{c}} / \mathrm{kg}\right)\end{array}$ \\
\hline \multirow{3}{*}{$\begin{array}{l}\text { Guinea } \\
\text { Savannah }\end{array}$} & Upper West & $4.9 \pm 0.3 \mathrm{a}$ & $10.1 \pm 4.3 \mathrm{a}$ & $5.6 \pm 0.6 \mathrm{c}$ & $0.5 \pm 0.3 \mathrm{a}$ & $11.1 \pm 0.9 \mathrm{ab}$ & $3.5 \pm 0.9 \mathrm{~b}$ & $35.0 \pm 13.0 \mathrm{c}$ & $8.0 \pm 0.4 \mathrm{e}$ & $4.1 \pm 2.1 \mathrm{c}$ \\
\hline & Upper East & $5.4 \pm 0.3 \mathrm{a}$ & $12.5 \pm 2.8 \mathrm{a}$ & $12.3 \pm 2.4 \mathrm{c}$ & $1.43 \pm 0.2 \mathrm{a}$ & $8.9 \pm 3.7 b$ & $9.1 \pm 5.3 b$ & $45.7 \pm 25.7 c$ & $6.6 \pm 0.6 \mathrm{e}$ & $10.6 \pm 4.0 \mathrm{~b}$ \\
\hline & Northern & $5.2 \pm 0.5 \mathrm{a}$ & $15.1 \pm 3.6 \mathrm{a}$ & $10.0 \pm 2.6 c$ & $3.53 \pm 3.1 \mathrm{a}$ & $9.6 \pm 0.7 \mathrm{ab}$ & $47.0 \pm 24.6 \mathrm{ab}$ & $23.1 \pm 2.54 \mathrm{c}$ & $11.9 \pm 0.8 \mathrm{~d}$ & $11.5 \pm 0.9 b$ \\
\hline \multicolumn{11}{|l|}{ Forest-Savannah } \\
\hline $\begin{array}{c}\text { Transitional } \\
\text { Zone }\end{array}$ & Brong-Ahafo & $5.4 \pm 0.3 \mathrm{a}$ & $12.0 \pm 5.2 \mathrm{a}$ & $21.3 \pm 4.2 \mathrm{~b}$ & $2.93 \pm 0.9 \mathrm{a}$ & $12.6 \pm 0.4 \mathrm{ab}$ & $70.1 \pm 16.9 \mathrm{ab}$ & $134.3 \pm 10.9 \mathrm{ab}$ & $20.6 \pm 1.4 \mathrm{c}$ & $15.6 \pm 1.3 \mathrm{~b}$ \\
\hline Deciduous & Ashanti & $5.2 \pm 0.5 \mathrm{a}$ & $18.3 \pm 4.2 \mathrm{a}$ & $28.0 \pm 1.9 \mathrm{~b}$ & $2.17 \pm 0.7 \mathrm{a}$ & $11.8 \pm 1.0 \mathrm{ab}$ & $88.7 \pm 10.4 \mathrm{a}$ & $107.4 \pm 18.9 \mathrm{~b}$ & $31.3 \pm 0.7 \mathrm{~b}$ & $22.5 \pm 1.8 \mathrm{a}$ \\
\hline Forest & Volta & $5.2 \pm 0.3 \mathrm{a}$ & $16.8 \pm 3.8 \mathrm{a}$ & $35.9 \pm 3.7 \mathrm{a}$ & $3.97 \pm 1.3 \mathrm{a}$ & $13.8 \pm 1.6 \mathrm{a}$ & $94.4 \pm 4.3 \mathrm{a}$ & $148.3 \pm 20.7 a$ & $47.9 \pm 0.3 \mathrm{a}$ & $27.4 \pm 2.3 \mathrm{a}$ \\
\hline
\end{tabular}

All data are expressed as mean $\pm \mathrm{SE}(\mathrm{n}=3)$, different letters within each column indicates statistically significate difference according to Tukey (T) test $(p<0.05)$. $\mathrm{C} / \mathrm{N}$ (carbon-to-nitrogen ratio), $\mathrm{NH}_{4}^{+}$(ammonia), $\mathrm{NO}_{3}^{-}$(nitrate), AP (available phosphorus), $\mathrm{CEC}$ (cation exchange capacity). 
Furthermore, within the DFZ, soils in the Volta region had higher $\mathrm{TC}, \mathrm{NO}_{3}{ }^{-}$, and $\mathrm{AP}$ contents compared to the Ashanti region, however, other soil parameters revealed no significant differences. Similarly, within the GSZ, no variations were observed among the three locations sampled, except that the Northern region had a higher AP content in comparison to the other two regions. Moreover, the soil in the Upper West region had a lower CEC value compared to the Northern and Upper East regions (Table 1). Overall, the soil samples from the DFZ showed consistently higher mean levels in the analyzed soil fertility parameters compared to the GSZ and Forest-Savannah transition zone (FSTZ).

\subsection{AMF Colonization Rates in Rice Roots Varied Across Six Regions in Ghana}

Microscopic observations showed that sampled rice roots were colonized by AMF, as evident in their structures, such as hyphae, arbuscules, or vesicles in the root cortical cells (Figure 2A). The most common structures observed in all samples among the regions were hyphae, followed by arbuscules and, less commonly, vesicles. The rate of AMF colonization ranged from $1.9 \%-22.9 \%$ among the regions (Figure $3 \mathrm{~B}$ ). The samples from the Upper West region exhibited the highest rate of colonization $(22.9 \%)$, followed by the Brong-Ahafo region (13.2\%), and the lowest rate of colonization was observed from root samples in the Volta region (1.9\%).

(a)

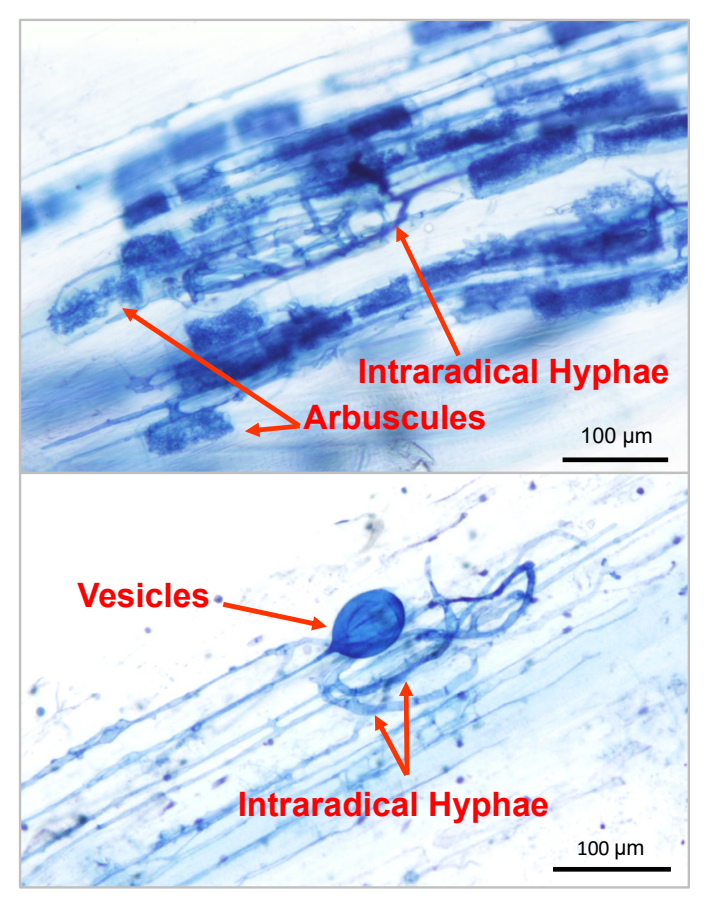

(b)

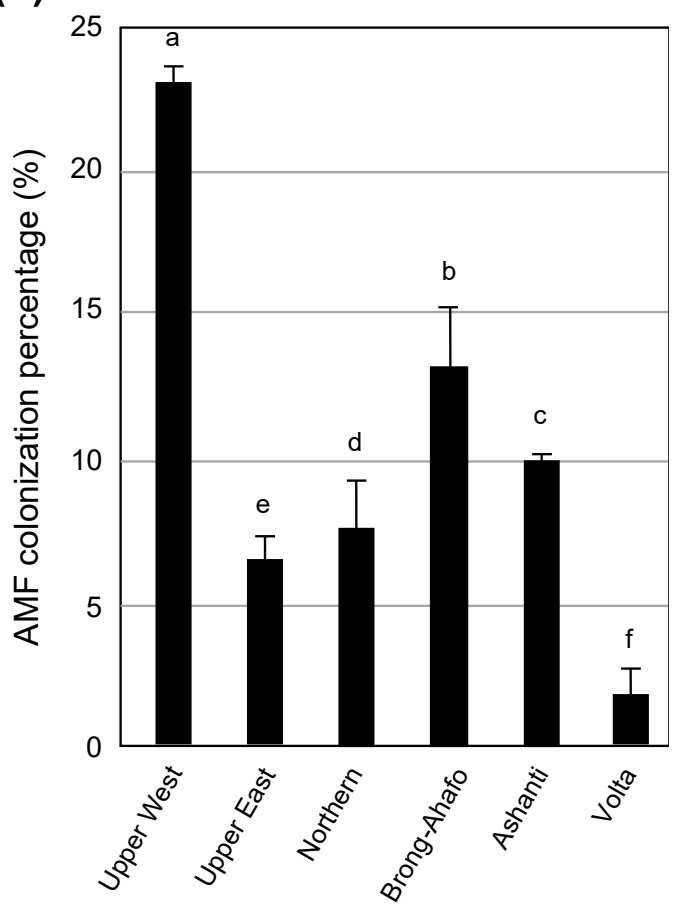

Figure 2. Arbuscular mycorrhizal fungi (AMF) colonization with rain-fed cultivated rice plants in Ghana: (a) Photomicrographs of structural colonization of AMF in rice roots stained with trypan blue solution. The observed morphological structures of AMF were hyphae, arbuscules, and vesicles. (b) The rate of AMF colonization in rice roots (based on the presence of hyphae, arbuscules, and vesicles) evaluated throughout the six different regions (Upper West, Upper East, Northern, Ashanti, Brong-Ahafo, and Volta) where rice roots were sampled from. Different letters (a, b, c, d, e, f) indicate significant differences between locations based on Tukey's test $(p<0.05)$. Sampling sites in rice-cultivated fields of Ghana with the study area colored in three different colors: (a) The map shows 57 sampling areas marked with black triangles among six different regions under three agroecological zones of Ghana. (b) Pictures of rice fields in Ghana where samples were collected. 
(a)

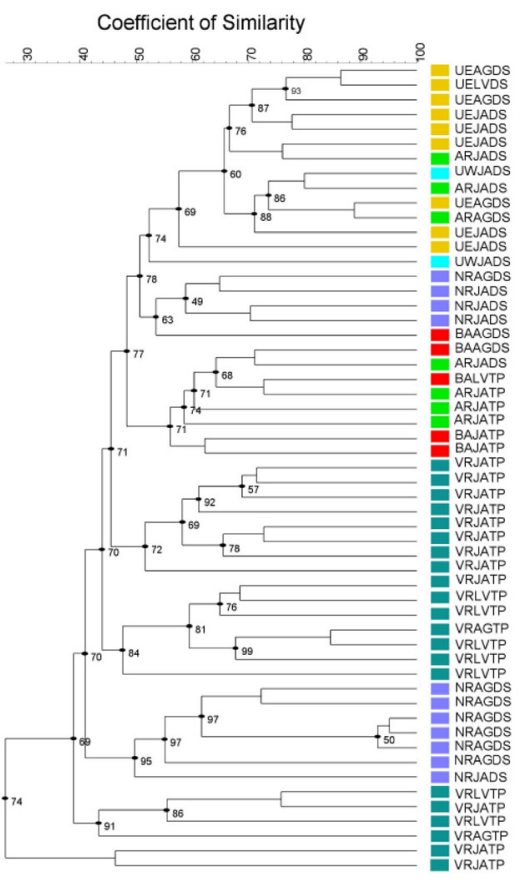

(b)

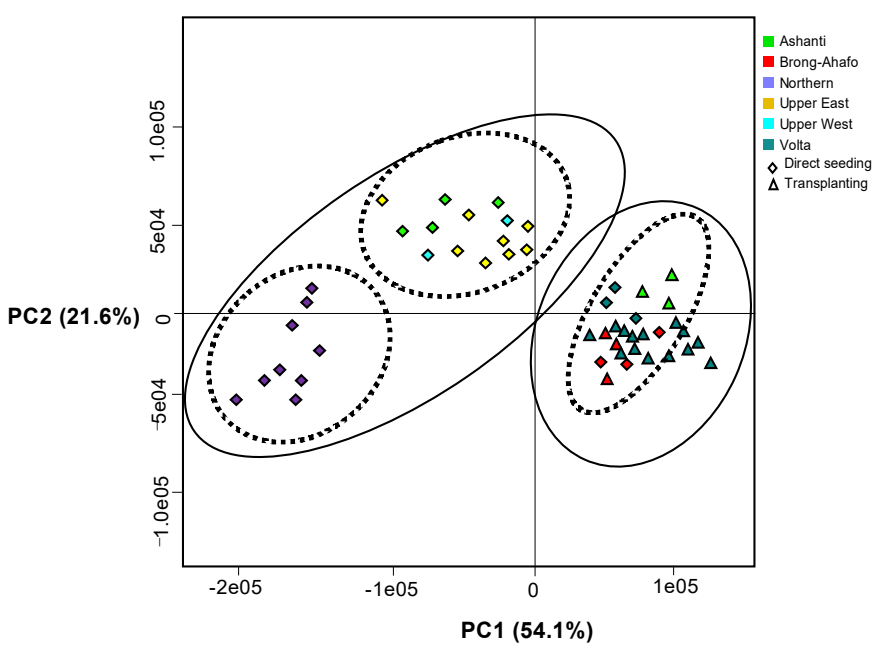

Figure 3. Comparison of results from clustering and ordination analysis of denaturing gradient gel electrophoresis (DGGE) profiles showing arbuscular mycorrhizal fungi (AMF) communities in colonized rice roots from six different regions in Ghana. (a) The dendrogram from the cluster analysis used a similarity matrix (Dice coefficient) based on region, rice cultivar, and farming system. The colors show the 6 sampled regions, namely, Ashanti (AR), Brong-Ahafo (BA), Northern (NR), Upper East (UE), Upper West (UW), and Volta (VR). Rice cultivar: Jasmine85 (JA), AgraRice (AG), and Local variety (LV); farming system: direct seeding (DS) and transplanting (TP). (b) Principal component analysis (PCA) with similarities explained by the first two components as $21.6 \%-54.1 \%$ of the variability. The diamond and triangle shapes represent the farming systems under which rice is cultivated.

\subsection{Farming Management Practices and Agroecological Zones Influenced Community Structure of AMF in} Rice Roots

Nested polymerase chain reaction-denaturing gradient gel electrophoresis (PCR-DGGE) amplification was used to assess AMF community structure in rice roots, with bands showing AMF species; according to a study by Formin et al. [46], DGGE bands represent a distinct taxon. The PCR-DGGE analysis displayed profiles characterized by a high number of distinct fragments (Figure S1). The DGGE fingerprints produced a total of 280 bands that varied across regions and ranged from three to ten per sample, as follows: (Upper West: $6.5 \pm 2.1$ ), (Upper East: $8.13 \pm 2.2$ ), (Northern: $5.25 \pm 1.7$ ), (Brong-Ahafo: $5.25 \pm 1.9$ ), (Ashanti: $2.94 \pm 2.9$ ), (Volta: $9.3 \pm 2.8$ ). No significant difference was detected in the number of bands counted among the regions.

The composition of AMF communities was assessed based on the cluster analysis of DGGE profiles (Figure 3A). The dendrogram showed eight significant groups with higher similarity (63-99\%) that were displayed among samples from the Upper East, Volta, and Northern regions, irrespective of the differences in rice cultivar and cultivation method. Our findings were confirmed through the principal component analysis, where PCA1 and PCA2 together revealed $75.7 \%$ of the variance in the AMF community (Figure 3B) in rice roots. The PCA1 that contributed the highest variation $(54 \%)$ in the dataset revealed that the cultivation method (direct seeding versus transplanting) had a profound impact on the AMF community in rice. The PCA2 explained 22\% variation and showed the regional influence on AMF community structure. As depicted in Figure 3B, the regions under DFZ and FSTZ were grouped together, however, the regions were not grouped in the GSZ. 


\subsection{Phylogenetic Analysis of the Excised DGGE Bands}

Based on the homology $(80 \%-100 \%)$ in the GenBank, we identified a total of 82 AMF taxa from our selected DGGE bands (Figure S2, Table S1). The most frequently identified sequences revealed the highest homology with Glomus, followed by Acaulospora, Rhizophagus, Archaeospora, Scutellospora, Claroideoglomus, and Gigaspora genera of AMF. A total of 41 out of 82 sequences showed the highest homology match with the fungal family Glomeraceae (27 Glomus and 14 Rhizophagus), 20 with Acaulosporaceae, 9 with Archaeosporaceae, 7 with Gigasporaceae, and 5 with Claroideoglomeraceae. The number of identified AMF species varied among different regions (Table S2), with Archaeospora detected only in the Upper East and Upper West regions. Among the identified species of AMF, Glomus dominated almost all the regions, except in the Ashanti, where the dominant AMF species was revealed to be Acaulospora.

\subsection{AMF Community Structure Analysis by Illumina MiSeq Sequencing}

Despite the agroecological effect that was demonstrated in AMF community structures in rice roots through PCR-DGGE profiling, the bands obtained by the DGGE profiles did not necessarily represent the actual population of AMF species and their relative abundances within each region. Therefore, advanced technology, specifically amplicon sequencing using Illumina sequencing, was applied to provide information on the definite number of AMF species present and to identify the factors that affected the community structures of AMF among the regions.

The Illumina sequencing of $18 \mathrm{~S}$ rRNA produced a total of 150,183 raw reads with an average read length of $236 \mathrm{bp}$. After the removal of nontarget and low sequence reads, we obtained 132,343 high-quality sequences read (88.12\%). The Basic Local Alignment Search Tool (BLAST) analysis ( $97 \%$ similarity cut-off) showed high homology to members of the Glomeromycota from 11 different genera. The rarefaction curve for the observed operational taxonomic units (OTUs) was predicted (Figure S3). ANOSIM analysis of the rarefied OTUs did not reveal any significant difference in AMF communities due to region or cultivar differences (Table S3). The alpha diversity indices, such as the Shannon diversity and Simpson dominance indices, were similar in all regions, while the observed OTUs showed some differences among the regions (Table 2), with the highest observation in roots from the Brong-Ahafo region and the lowest from the Upper East region. However, Chao1, an index representing the species richness in a community, showed a significant difference between samples from the Upper East and Volta regions. The most dominant genera in all the regions were Rhizophagus and Glomus, except for the Upper West region which was dominated by Scutellospora and Acaulospora (Figure 4). Rhizophagus, Glomus, Acaulospora, and Scutellospora were the only genera found in the Ashanti region. The Northern region showed greater diversity compared to the other regions. Concerning the abundance of AMF genera, we did not observe any significant differences across the six regions. The Permutational Multivariate Analysis of Variance Analysis (PERMANOVA) indicated that the community composition of AMF in rice roots from the relative abundance of different OTUs was significantly affected (Table 3 ) by the measured content of AP independently $(p<0.05)$, as well as by the interactions between $\mathrm{AP}$ and the carbon-to-nitrogen ratio (C/N; PERMANOVA, $p<0.05), \mathrm{P}$ and nitrate $\left(\mathrm{NO}_{3}{ }^{-}\right.$; PERMANOVA, $p<0.05$ ), and $\mathrm{C} / \mathrm{N}$ and $\mathrm{NO}_{3}{ }^{-}$(PERMANOVA, $p<0.05$ ), but not by the difference in regions or the cultivars of rice. This was shown in the Mantel statistical analysis based on Spearman's rank correlation of each OTU (Table S4). Several OTUs correlated either positively or negatively $\left(R^{2}>0.8-0.9\right)$ with either AP or C/N except for OTU3544, OTU5961, OTU72, and OTU3698 (Glomus), which correlated positively with $\mathrm{AP}$ and $\mathrm{C} / \mathrm{N}$. 
Table 2. AMF diversity and species richness. Alpha-diversity metrics of samples based on rarefied operational taxonomic units (OTUs) in analyzed rice roots sampled from different regions across Ghana.

\begin{tabular}{ccccc}
\hline Region & Observed OTU & Shannon & Simpson & Chao1 \\
\hline Upper West & $222.50 \pm 84.15 \mathrm{a}$ & $0.68 \pm 0.09 \mathrm{a}$ & $1.93 \pm 0.16 \mathrm{a}$ & $293.62 \pm 136.49 \mathrm{ab}$ \\
Upper East & $138.33 \pm 119.26 \mathrm{a}$ & $0.57 \pm 0.50 \mathrm{a}$ & $1.83 \pm 1.59 \mathrm{a}$ & $158.1 \pm 132.7 \mathrm{~b}$ \\
Northern & $242.33 \pm 99.50 \mathrm{a}$ & $0.74 \pm 0.17 \mathrm{a}$ & $2.29 \pm 0.67 \mathrm{a}$ & $472.32 \pm 186.56 \mathrm{ab}$ \\
Brong-Ahafo & $461.00 \pm 173.52 \mathrm{a}$ & $0.89 \pm 0.06 \mathrm{a}$ & $3.24 \pm 0.72 \mathrm{a}$ & $308.97 \pm 45.84 \mathrm{ab}$ \\
Ashanti & $227.67 \pm 44.11 \mathrm{a}$ & $0.80 \pm 0.10 \mathrm{a}$ & $2.54 \pm 0.32 \mathrm{a}$ & $340.31 \pm 94.77 \mathrm{ab}$ \\
Volta & $278.33 \pm 76.77 \mathrm{a}$ & $0.79 \pm 0.09 \mathrm{a}$ & $2.40 \pm 0.40 \mathrm{a}$ & $252.03 \pm 59.67 \mathrm{a}$ \\
\hline
\end{tabular}

Values are mean $\pm \mathrm{SE}(\mathrm{n}=3)$. Different letters indicate statistically significant differences $(p<0.05)$ between regions according to the Tukey-Karmer (T) test.
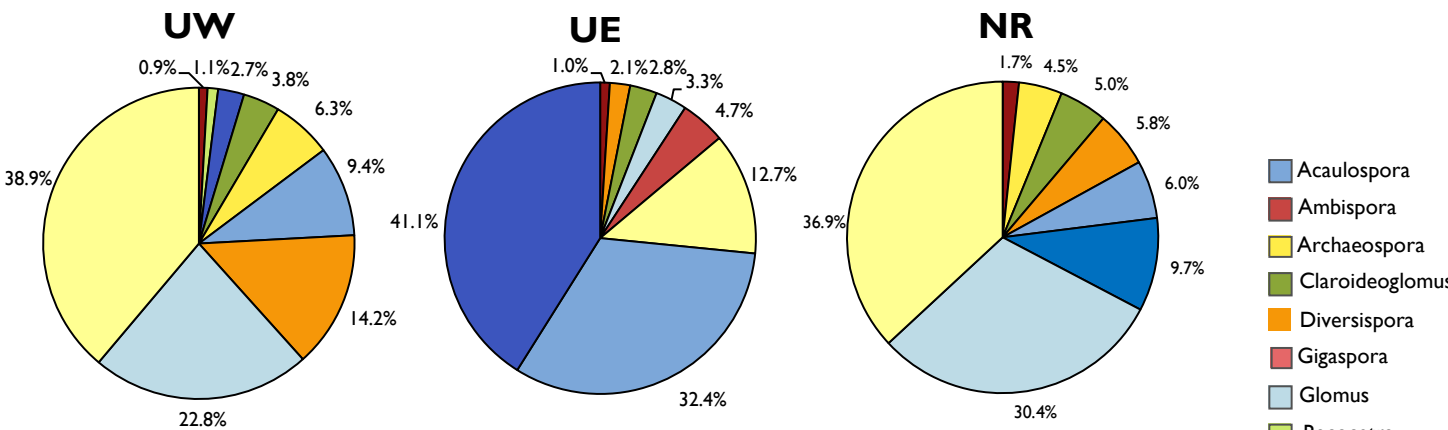

BA
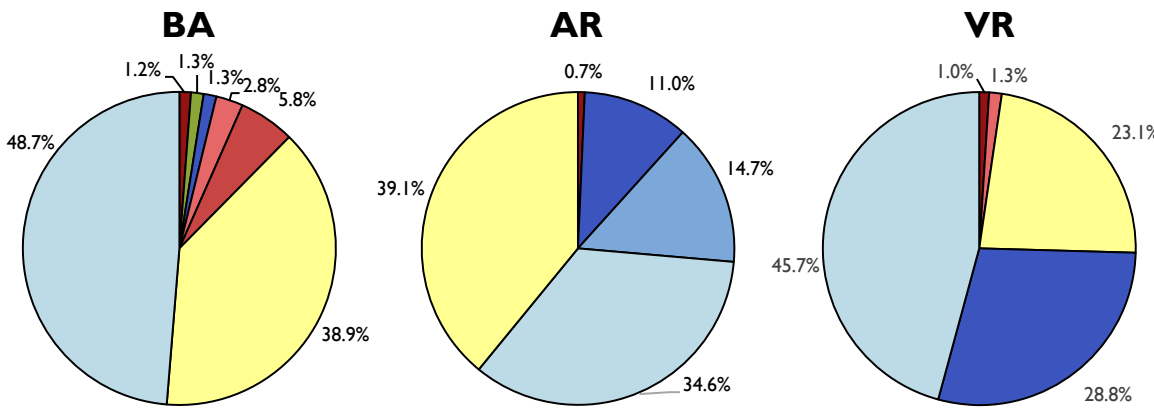

$\square$ Racocetra

$\square$ Redeckera

$\square$ Rhizophagus

Scutellospora

Others

Figure 4. The relative abundance of total number of read operational taxonomic units (OTUs) grouped by AMF genus among six different regions in Ghana. UW: Upper West; UE: Upper East; NR: Northern; AR: Ashanti; VR: Volta.

Table 3. PERMANOVA analysis of the effect of available $\mathrm{P}$, carbon-to-nitrogen ratio $(\mathrm{C} / \mathrm{N}), \mathrm{NO}_{3}{ }^{-}$and their interactions on the distribution of AMF OTUs in analyzed rice roots sampled from six different regions across Ghana. * $p<0.05$.

\begin{tabular}{ccccccc}
\hline Soil Chemical Properties & Df & Sum of Squares & Mean Squares & F. Model & $\mathbf{R}^{\mathbf{2}}$ & $\operatorname{Pr}(>\mathbf{F})$ \\
\hline Available $\mathrm{P}$ & 1 & 0.519 & 0.519 & 1.591 & 0.071 & $0.041^{*}$ \\
$\mathrm{C} / \mathrm{N}$ & 1 & 0.432 & 0.432 & 1.326 & 0.059 & 0.137 \\
$\mathrm{NO}_{3}{ }^{-}$ & 1 & 0.327 & 0.327 & 1.002 & 0.045 & 0.443 \\
$\mathrm{AP} \times \mathrm{C} / \mathrm{N}$ & 1 & 0.557 & 0.558 & 1.710 & 0.077 & $0.021^{*}$ \\
$\mathrm{AP} \times \mathrm{NO}_{3}^{-}$ & 1 & 0.584 & 0.584 & 1.793 & 0.080 & $0.015^{*}$ \\
$\mathrm{C} / \mathrm{N} \times \mathrm{NO}_{3}^{-}$ & 1 & 0.509 & 0.509 & 1.561 & 0.070 & $0.049^{*}$ \\
$\mathrm{AP} \times \mathrm{C} / \mathrm{N} \times \mathrm{NO}_{3}{ }^{-}$ & 1 & 0.428 & 0.428 & 1.313 & 0.059 & 0.145 \\
Residual & 12 & 3.911 & 0.326 & & & \\
\hline Total & 19 & 7.266 & 1 & & &
\end{tabular}




\section{Discussion}

In the present study, we combined morphological analysis and molecular genetics to investigate the diversity and community compositions of native AMF in rice roots that were grown under field conditions in different regions across Ghana. Our data showed that agroecology, soil physicochemical properties, and farm management practices (cultivation method) influence the composition of the indigenous AMF community in rice. For the first time, we identified native AMF species (at the genus level) that colonize rice roots from different rice ecologies in Ghana and characterized the dynamics of their community compositions.

In the present study, the rate of AMF colonization in rice roots was used to assess the activity of AMF communities indirectly among the regions. Unlike previous studies $[44,47,48]$, we detected AMF associations in roots at the vegetative stage of rice growth, indicating that root colonization by AMF occurred earlier and not at the reproductive stage as proposed by other investigations. For instance, Wang et al. [49] and Watanarojanaporn et al. [50] proposed that AMF colonization in rice roots was observed much more frequently at the mature stage (heading and ripening) and also at the early stage of growth before flooding. In the present study, soil moisture levels were often controlled by rainfall patterns under a rain-fed rice cultivation system, therefore, higher AMF colonization at the early stage of host growth was obserevd. Moreover, colonization was observed to occur at an early stage of growth because the involved indigenous AMF species possibly adapted to the ecological conditions under rain-fed systems, thereby enabling them to colonize at an early stage of host growth. However, further research is still required for clarification. The rate of colonization by AMF in sampled rice roots displayed a considerably similar range $(1.9 \%-22.9 \%)$ compared to that reported in other rice plants grown in different environments as well as in other crops, such as wheat [51,52]. Among the six regions included in the present study, significantly different colonization percentages were observed. The cause of these variations is currently unknown, however, this could be attributed to several factors, including climatic variables, rice variety, soil fertility, and farm management practices [50,53,54].

Molecular profiling of AMF communities through nested PCR-DGGE and high throughput Illumina sequencing in the present study revealed that AMF community structures in rice roots varied across the agroecological locations and were influenced significantly by soil properties. The cluster analysis of PCR-DGGE profiles revealed the region as the major factor driving AMF communities in rice roots, irrespective of the differences in rice cultivars and cultivation methods applied during production. This finding was in agreement with the results of a previous study in West Africa [55], where community composition of AMF associated with yam production was influenced by differences in ecological zones. This finding was further supported by another previous study [56], which reported that the geographical distance had a significant impact on the community structures of AMF in grazed grassland across Sweden. Furthermore, Casazza et al. [57] reported differences observed in AMF community structures found in Berardia subacaulis among diverse sites in the Southwestern Alps. In this survey, the multivariate analysis (PCA) based on PCR-DGGE profiles further illustrated the impact of other variables, including cultivation methods on the composition of AMF communities in roots from six different regions. Direct seeding was used as the dominating method that influenced AMF community structures in all regions, except for the Brong-Ahafo and Volta regions. The farm management practices, such as cultivation methods, were among the factors reported in several studies to severely affect AMF community structures and distributions $[33,44,58]$. As reported in recent studies, a single factor is unable to influence the composition of AMF communities itself, however, combinations of factors (biotic and abiotic) regulate AMF communities and their distribution $[33,36,59,60]$ by contributing significantly to agricultural sustainability.

Though AMF diversity in rice roots was observed to be the first of its kind in Ghana, the sequences obtained from excised DGGE bands corresponded to an already known AMF taxon [61]. The sequence analysis of PCR-DGGE bands did not provide extensive coverage of the phylum Glomeromycota. Only 7 out of 21 genera and 4 out of 11 families were observed to be common across all the regions [61], suggesting low AMF diversity in rice. Glomus was the most frequently encountered AMF phylotype 
in all regions, except for the Ashanti region. The predominance of Glomus phylotypes in rice plants was revealed by several studies, irrespective of the conventional (wet paddy) system or production under rain-fed conditions [49-51,62]. The consistent occurrence of Glomus in these varying conditions of production indicated that the genus Glomus could withstand several environmental conditions and was adapted to various ecosystems [40,61]. The genus Archaeospora was found only in the Upper East and Northern regions, implying that this genus may be localized to some particular environmental conditions. Although the Northern, Upper East, and West regions are under the same agroecological zone, the distribution of Archaeospora in these two regions might be influenced by other factors unrelated to agroecological distance.

In the PCR-DGGE analysis, the number and intensity of bands illustrated on DGGE profiles did not necessarily represent AMF diversity and the actual abundance of species present in a microbial community [63]. Therefore, Illumina sequencing was performed for a more precise assessment of AMF diversity and species richness within the three different rice ecologies among the six regions, and to characterize their community compositions. A total of 67 OTUs were detected after rarefying, corresponding to an already known AMF taxon discussed in previous studies $[40,61,64]$. The read OTUs revealed 7 out of 11 families and 12 out of 24 genera of the phylum Glomeromycota, yet the AMF diversity, as expressed by the Shannon-Weaver (0.57-0.89) and Simpson-dominance diversity indices (1.83-3.24), were not consistent among different regions, which was confirmed by the significant differences observed by the Chao1 richness index of rice roots. However, these were observed to be somewhat higher in comparison to previous reports from arable fields based on plant roots $[65,66]$. The AMF species identified at the genus level include Acaulospora, Ambispora, Archaeospora, Claroideoglomus, Diversispora, Gigaspora, Glomus, Racocetra, Redeckera, Rhizophagus, and Scutellospora. Our findings also indicated that Glomus and Rhizophagus were the abundant species in rice roots among all regions, except for the Upper East region, where Scutellospora and Acaulospora were dominant. Nonetheless, in previous reports, Glomus were described as the leading AMF species in roots and soil [67-69], though the species abundance in roots was a fraction of that found in the rhizosphere. The switch observed in the distribution of AMF species in the Upper East region was an indication of the biotic and abiotic effects on AMF community compositions. Across the agroecological zones, we observed a vast difference in species distribution among GSZ, FSTZ, and DFZ. The GSZ showed the highest AMF diversity (ranging from eight to nine AMF species per region) compared to FSTZ and DFZ. Factors contributing to these distinct variations among the regions under these zones are currently unknown. However, the influence of agroecological activities cannot be eliminated based on its effects on AMF communities, as reported by previous studies [22,45,70-72].

For the characterization of AMF in plant roots, numerous studies reported biotic factors as the major components actively regulating community composition [35,73,74]. However, in the present study, some abiotic factors (particularly soil properties) were detected as relevant characteristics based on PERMANOVA analysis. PERMANOVA revealed a significant effect $(p<0.05)$ of AP on the AMF community structure in sampled rice roots. The AP content in soil varied among the regions, with the highest level observed in the Volta region $(47.9 \mathrm{mg} / \mathrm{kg})$ and the lowest in the Upper East and Upper West regions $(6.6-8.0 \mathrm{mg} / \mathrm{kg})$. Although the Northern, Brong-Ahafo, and Ashanti regions also showed high AP levels, under the agroecological zones, the GSZ was observed to possess the lowest level compared to the FSTZ and DFZ. In previous studies, it was demonstrated that the soil physiochemical properties affected the composition of AMF communities and influenced their distribution and performance in the agricultural environment $[30,42,60,75-78]$. In the present study, the AMF communities based on the observed OTUs were affected independently by AP content and their interactions with other nitrogen source elements, such as $\mathrm{NO}_{3}{ }^{-}$and $\mathrm{C} / \mathrm{N}$. Soil $\mathrm{NO}_{3}{ }^{-}$and $\mathrm{C} / \mathrm{N}$ showed no effects on AMF communities in roots, except when an interaction between them was observed. The recorded AP content from the surveyed rice fields mentioned previously in the present study was perceived as the principal factor shaping AMF community structures in rice roots among the different regions. Although the relationship between the rate of AMF colonization with their host plants and the physicochemical 
properties of soil vary among ecosystems, the response of AMF species to the mineral environment is also known to differ [79]. In previous studies, Hijri et al. [65] and DeBeenhouwer et al. [22] suggested a negative effect of soil AP on AMF community structures, whereas the findings of other studies were in contrast with these findings, suggesting no linkage between AMF diversity and AP $[60,80]$. The findings were in agreement with a previous study by Yoshimura et al. [81], who reported that the rate of AMF colonization in Japanese pear correlated with the AP content in the soil. In the present study, AP contents were observed to be higher $(47 \mathrm{mg} / \mathrm{kg})$ and the colonization percentage was observed to be very low $(1.9 \%)$, while the highest colonization percentage was recorded $(22.9 \%)$ in locations where the AP contents were recorded to be low $(8.0 \mathrm{mg} / \mathrm{kg})$. Since the surveyed rice fields among the six regions differed in agroecological zones, the variations in AP alone could not explain the discrepancy in AMF colonization rate and Alpha diversity indices; further research is required in this aspect for better understanding. These results are useful in providing an understanding for future studies focusing on the functional benefits of AMF during the development of sustainable rice production systems, particularly on the potential application of AMF for improved nutrient acquisition and soil moisture utilization in rice cultivation systems.

\section{Materials and Methods}

\subsection{Site Description and Sampling Materials}

The present study was carried out in six major rice-producing regions in Ghana. The regions included the Upper West, Upper East, Northern, Ashanti, Brong-Ahafo, and Volta regions (Figure 1), which are categorized under three agroecological zones, including the Guinea Savannah zone (Upper West, Upper East, and Northern regions), the Forest-Savannah transition zone (Brong-Ahafo region), and the deciduous forest zone (Ashanti and Volta regions). The FSTZ and DFZ are characterized by a bimodal annual rainfall $(1300 \mathrm{~mm})$ and a mean annual temperature of $30^{\circ} \mathrm{C}$, whereas the GSZ has a unimodal rainfall pattern $(1000 \mathrm{~mm})$ with a $35^{\circ} \mathrm{C}$ average temperature, according to the Ghana Meteorological Agency (1983-2012). The soils in FSTZ and DFZ are typically well-drained loamy soil (rich in organic matter), and GSZ has sandy soil that is low in organic matter and highly receptive to erosion $[4,82,83]$.

Rice farmers from these regions often acquire rice seeds (cultivars Jasmine85 and AgraRice and local cultivars) from agrochemical shops. Rice seeds acquired for production are mostly untreated with pesticides before sowing. Rice cultivation in these locations is carried out following two main methods, namely, direct seeding and transplanting. In the direct seeding method, seeds are sown directly in the field either by dibbling or broadcasting, whereas in the transplanting method, seeds are nursed close to the fields and seedlings are transferred later onto the main field for production.

In this study, healthy rice plants (cultivars Jasmine85 and AgraRice and local cultivars), at an average height of about $55 \mathrm{~cm}$ and in their vegetative (tiller) stage, were collected randomly from eight different spots within each cultivated field and then pooled as a sample. Roots from sampled rice plants were washed with tap water to remove adhering soils debris and stored at $-30{ }^{\circ} \mathrm{C}$ until further use. Soil ( $0-15 \mathrm{~cm}$ depth), often moist, was also sampled from the same rice fields at eight different core spots using an auger. The roots and soil samples collected from each field represented an individual a sample per field. Likewise, about nine different fields in each region were sampled, except for the Volta region where samples were collected from twelve different fields, making a total of 57 root and 57 soil samples. The rice roots and soil samples were collected in August-September 2016.

\subsection{Soil Analysis}

Various soil properties, such as $\mathrm{pH}$, moisture content, $\mathrm{TC}$, total nitrogen (TN), and the soil carbon-to-nitrogen ratio $(\mathrm{C} / \mathrm{N})$ were analyzed following the standard protocols for tropical soils [84]. The AP was extracted using sulfuric acid and ammonium sulfate $\left(\mathrm{NH}_{4}\left(\mathrm{SO}_{4}\right)_{2}, \mathrm{pH} 3\right)$ solution using the Truog-soluble method [85]. Ammonia $\left(\mathrm{NH}_{4}{ }^{+}\right)$and nitrate $\left(\mathrm{NO}_{3}{ }^{-}\right)$contents were determined 
via the continuous flow injection analysis method and the indophenol-blue colorimetric procedure, respectively, after extracting $10 \mathrm{~g}$ soil with $2 \mathrm{M} \mathrm{KCl}$ solution [86]. The CEC content was measured using the Schollenberger and Simon method [87].

\subsection{Assessment of AMF Colonization in Roots}

The rate of AMF colonization in rice roots was estimated according to the magnified interaction method based on trypan blue staining [88], with some minor modifications. Briefly, roots were cut into about $1 \mathrm{~cm}$ fragments, cleared in $10 \% \mathrm{KOH}$ (potassium hydroxide) boiling solution, stained with $0.05 \%$ trypan blue-lactic acid solution, and destained by transferring into a freshly prepared lactoglycerol solution for $48 \mathrm{~h}$. Thirty randomly selected stained root fragments $(1 \mathrm{~cm})$ per sample were examined for AMF colonization following the procedures described by McGonigle et al. [52].

\subsection{DNA Extraction and Nested PCR}

Fresh rice root samples were ground into a fine powder with liquid nitrogen using a sterilized mortar and pestle. DNA was extracted from roots $(100 \mathrm{mg})$ using the DNeasy plant mini kit (Qiagen, Hilden, Germany) following the manufacturer's recommendations. The isolated DNA was subjected to nested PCR amplification using AMF specific primers, including AMV4.5F/AMV4.5R [89] and GC-AMV4.5NF/AMDGR [48,89]. The first PCR reaction was prepared in a final volume of $25 \mu \mathrm{L}$ and comprised of DNA template $(10 \mathrm{ng} / \mu \mathrm{L})$, AmpliTaq Gold ${ }^{\circledR} 360$ polymerase $(0.13 \mu \mathrm{L}$; Thermo Fisher Scientific, USA), PCR buffer (10 $\times)$, forward and reverse primers $\left(10 \mu \mathrm{M}\right.$ each), dNTPs $(2.5 \mathrm{mM}), \mathrm{MgCl}_{2}$ $(25 \mathrm{mM})$, and distilled water $(15.375 \mu \mathrm{L})$. The conditions used for PCR reaction were as follows: $95^{\circ} \mathrm{C}$ for $10 \mathrm{~min}, 30$ cycles of denaturation at $94{ }^{\circ} \mathrm{C}$ for $30 \mathrm{~s}$, primer annealing at $55^{\circ} \mathrm{C}$ for $30 \mathrm{~s}, 1 \mathrm{~min}$ extension at $72{ }^{\circ} \mathrm{C}$, and a final extension period of $9 \mathrm{~min}$ at $72{ }^{\circ} \mathrm{C}$ using the Veriti 96 Wells Thermal Cycler (Applied Biosystems; California, USA). The first PCR product was purified using FastGene Gel/PCR Extraction kit (NIPPON Genetics, Japan).The purified PCR product was diluted (1:10) with sterilized distilled $\mathrm{H}_{2} \mathrm{O}$ and used as a DNA template in the second PCR reaction. The second PCR amplification was carried out following similar conditions as the first PCR reaction, except for a change in the final volume of $50 \mu \mathrm{L}$.

\subsection{DGGE Analysis}

DGGE analysis was performed using DCode Universal Mutation Detection System (Bio-Rad Laboratories; CA, USA) following the method as described by Muyzer et al. [90], with minor modifications. DGGE fingerprints were loaded onto $7 \%(\mathrm{w} / \mathrm{v})$ polyacrylamide gel (37:5:1 acrylamide/bis-acrylamide) with a linear denaturing gradient of $20 \%-40 \%$ denaturant ( $100 \%$ denaturant solution containing $7 \mathrm{M}$ urea and $40 \%(\mathrm{v} / \mathrm{v})$ formamide) and run for $20 \mathrm{~h}$ at $50 \mathrm{~V}$ under a constant temperature of $60{ }^{\circ} \mathrm{C}$. Gels were photographed after staining with SYBR ${ }^{\circledR}$ Green I Nucleic acid gel stain (Takara Bio) for $40 \mathrm{~min}$ and unstained in a 1× Tris-acetate EDTA buffer at room temperature [89].

\subsection{DGGE Band Sequencing}

A total of 280 bands were detected after DGGE analysis; thereafter, 101 bands were excised from polyacrylamide gel and kept at $5{ }^{\circ} \mathrm{C}$ overnight in $250 \mu \mathrm{L}$ sterilized MilliQ water. DNA was eluted from these bands after incubating overnight using the Poly-Gel DNA Extraction Kit (OMEGA, USA), following the manufacturer's instructions. Extracted DNA was used as a template for PCR reamplification following the same conditions as before, using the primers AMV4.5NF/AMDGR before sequencing. Sequences obtained were compared to AMF sequences in the GenBank database through the BLAST program (http://www.ncbi.nlm.nih.gov/BLAST) with a varying threshold of nucleotide identity $(90.9 \%-100 \%)$. The sequences were aligned using the MacVector sequence analysis tool (https://macvector.com). Maximum likelihood (ML) analyses of the partial 18S rRNA gene region were performed using the Molecular Evolutionary Genetic Analysis X (MEGA X) program with bootstrap support obtained using 1000 replicates [91]. The sequences obtained in the present study were also 
deposited at the DNA Data Bank of Japan (DDBJ) http://www.ddbj.nig.ac.jp/search/top-e.html) with the accession number LC516092 -LC516173.

\subsection{Next-Generation Sequencing}

Amplicon sequencing of the 18S rRNA gene was carried out on the MiSeq platform at Bioengineering Lab. Co. (Atsugi, Japan) for 20 samples based on the location, rice variety (Jasmine85), and cultivation method. Firstly, a nested PCR using primers AMV4.5F/AMV4.5R and AMV4.5NF/AMVR was performed. A DNA library was generated after purification of the second PCR product using AMPure XP (Beckman Coulter). The purified product was then quantified using Synergy H1 (Bio Tek) and QuantiFlour dsDNA system. A quality check of the libraries was done using Fragment Analyzer and dsDNA 915 Reagent Kit (Advanced Analytical Technologies). DNA libraries were pooled together and loaded on an Illumina MiSeq instrument following the manufacturer's instructions (Illumina, San Diego, CA, USA). The Quantitative Insights into Microbial Ecology (QIIME) toolkit [92] was used to process the raw high-throughput sequencing data. Excluding the barcodes and standard primer sets, sequence reads not meeting the quality filtering $<20$ criterion and those fewer than $200 \mathrm{bp}$ in length were discarded [93]. Denoising was performed using the built-in denoiser algorithm and chimera removal. OTU picking was done (http://www.drive5.com/usearch/download.html) at a pairwise identity percentage of 0.97 using the sequence analysis tool USEARCH 61. Taxonomy assignment was performed using the Ribosomal Database Project naïve Bayesian classifier using a minimum confidence of 0.8 against the Greengenes database (October 2012 release; http://greengenes.secondgenome.com/) and BLAST (https://blast.ncbi.nlm.nih.gov/Blast.cgi).

\subsection{Statistical Analysis}

All data obtained were subjected to statistical analyses. Analysis of variance (ANOVA) and Tukey's pairwise comparisons $(p<0.05)$ were conducted to compare the means for each variable using the statistical software Minitab version 18 (Minitab Inc., State College, PA). For DGGE fingerprint data, clustering and PCA analysis were performed based on the presence or absence of a band using Bionumerics ${ }^{\circledR}$ software package (version 7.6.3; Applied Maths, Sint-Martens-Latem, Belgium), following the procedures as described by Gomes et al. [94]. The abundance of OTUs per sample and the Bray-Curtis distances recorded after Illumina MiSeq sequencing resulted in series of AMF community-related analyses carried out using the R program, version 3.5.2 (Eggshell Igloo, 2018), using the package "vegan" 2.5-3. The $\alpha$-diversity indices (Shannon, Simpson, and Chao1) of AMF within each location were estimated, and the significant differences were estimated using the Tukey-Karmer test $(p<0.05)$. PERMANOVA was used to assess the differences in AMF community structures and their relationships with the chemical properties of soil across the locations.

\section{Conclusions}

Although the benefits of AMF symbiosis are well known, limited studies exist regarding the AMF symbiosis under the agricultural system and their applications regarding crop production in Ghana. In this study, we reported on the AMF diversity and community structures of rice roots in six regions under three agroecological zones for the first time in Ghana. Soil properties were identified as the key environmental factors affecting AMF communities with rice production among the regions. The AP contents detected played a significant role in the dynamics of AMF communities. Thus, assessing the effect of AP levels in shaping AMF communities and the impact on an improved rice production system is recommended for future studies. Overall, these findings shed light on the diversity, community structures, and drivers of AMF with rice in arable soils for sustainable production.

Supplementary Materials: The following are available online at http://www.mdpi.com/2073-4395/10/4/559/s1, Figure S1: DGGE profile of 18S rRNA fragments of AMF communities in rice roots sampled from six different regions in Ghana; Figure S2: Phylogenetic tree of arbuscular mycorrhizal fungi (AMF) colonizing rice roots from Ghana; Figure S3: Rarefaction curves of AMF species for all analyzed rice root samples from six different regions 
in Ghana; Table S1: AMF species identified from sequencing excised DGGE band fragments of sampled rice roots collected from six different regions in Ghana and their closest similarity percentages based on NCBI-BLAST search; Table S2: The number of AMF species identified among six different regions in Ghana based on PCR-DGGE band profiles; Table S3: AMOSIM analysis of the effects of rice varieties and sampling locations on AMF community structures in analyzed rice roots based on rarefied OTUs; Table S4: Mantel analysis based on Spearman's rank correlation among each OTU and available phosphorus (AP) or carbon-to-nitrogen ratio (C/N).

Author Contributions: Conceptualization, E.S.-A. and S.O.; methodology E.S.-A., S.O., R.A.O., S.O.A., R.B., and S.A.-B.; validation, E.S.-A. and S.O.; formal analysis, E.S.-A. and S.O.; investigation, E.S.-A. and S.O.; resources, S.O., Y.F., S.O.A., R.B., and S.A.-B.; data curation, E.S.-A., S.O., R.A.O., C.G.L., M.Y., M.K., and K.M.G.D.; writing-Original draft preparation, E.S.-A.; writing-Review and editing, E.S.-A., S.O., C.G.L., M.Y., and K.M.G.D.; visualization, E.S.-A.; supervision, S.O.; project administration, S.O.; funding acquisition, S.O. All authors have read and agreed to the published version of the manuscript.

Funding: This research was funded by Japan Society for the Promotion of Science (no. 120199926).

Acknowledgments: The authors appreciate the assistance from Beloved Mensah Dzomeku and Allen Oppong (PhD) (CSIR-Crops Research Institute, Kumasi) for allowing us to use their laboratories and Alex Yeboah (CSIR-Savanna Agricultural Research Institute, Tamale) during plant and soil sampling.

Conflicts of Interest: The authors declare no conflict of interest.

\section{References}

1. Muthayya, S.; Sugimoto, J.D.; Montgomery, S.; Maberly, G.F. An overview of global rice production, supply, trade, and consumption. Ann. N. Y. Acad. Sci. 2014, 1324, 7-14. [CrossRef] [PubMed]

2. Archibald, D.; Taylor, J. Grain and Feed Annual; USDA Foreign Agricultural Service: Washington, DC, USA, 2018; p. 7.

3. Ministry of Food and Agriculture (MoFA). Agriculture in Ghana: Facts and Figures, 2015; Annual Report by the Statistics, Research and Information Directorate (SRID), MoFA, as Part of MoFA's Policy Planning, Monitoring and Evaluation Activities; Ministry of Food and Agriculture: Accra, Ghana, 2016.

4. Ministry of Food and Agriculture (MoFA). Agricultural Progress Report_Final, 2017. Available online: http://www.PPMED.MoFA.pdf (accessed on 5 July 2017).

5. Ghana Statistical Service (GSS). Rebased 2013-2018 Annual Gross Domestic Product; Ghana Statistical Service: Accra, Ghana, 2019; Volume 11.

6. Ministry of Food and Agriculture (MoFA). 2013 Agric Sector Annual Progress Report; Ministry of Food and Agriculture (MoFA): Accra, Ghana, 2013; Volume 96.

7. Food and Agricultural Organization (FAO). Country Fact Sheet on Food and Agriculture Policy Trends-Ghana; Food and Agricultural Organization (FAO): Rome, Italy, 2015; Available online: http://www.fao.org/ag/agp/ agpc/doc/counprof/PDF\%20files/Ghana-English.pdf (accessed on 6 May 2019).

8. Ministry of Food and Agriculture (MoFA). National Rice Development Strategy-Draft: A Draft Report of the Ministry of Food and Agriculture; Ministry of Food and Agriculture: Accra, Ghana, 2009.

9. Kajisa, K. On the Determinants of Low Productivity of Rice Farming in Mozambique: Pathways to Intensification. In Pursuit of an African Green Revolution: Views from Rice and Maize Farmers' Fields; Natural Resource Management and Policy; Springer: Tokyo, Janpan, 2016; pp. 13-38. ISBN 978-4-431-55693-0.

10. Saito, K.; Nelson, A.D.; Zwart, S.J.; Niang, A.; Sow, A.; Yoshida, H.; Wopereis, M.C.S. Towards a better understanding of biophysical determinants of yield gaps and the potential for expansion of the rice area in Africa. Realiz. Afr. Rice Promise 2013, 188-203. [CrossRef]

11. Diagne, A.; Amovin-Assagba, E.; Futakuchi, K.; Wopereis, M.C.S. Estimation of cultivated area, number of farming households and yield for major rice-growing environments in Africa. In Realizing Africa's Rice Promise; Wopereis, M.C.S., Johnson, D.E., Ahmadi, N., Tollens, E., Jalloh, A., Eds.; CABI: Wallingford, UK, 2013; pp. 35-45. ISBN 978-1-84593-812-3.

12. Bado, V.B.; Djaman, K.; Valère, M.C. Managing Fertilizer Recommendations in Rice-Based Cropping Systems Challenges and Strategic Approaches; Springer International Publishing: Basel, Switzerland, 2018; Volume 1, pp. 25-50. ISBN 978-3-319-58789-9.

13. Tanaka, A.; Johnson, J.-M.; Senthilkumar, K.; Akakpo, C.; Segda, Z.; Yameogo, L.P.; Bassoro, I.; Lamare, D.M.; Allarangaye, M.D.; Gbakatchetche, H.; et al. On-farm rice yield and its association with biophysical factors in sub-Saharan Africa. Eur. J. Agron. 2017, 85, 1-11. [CrossRef] 
14. Haefele, S.M.; Saito, K.; N’Diaye, K.M.; Mussgnug, F.; Nelson, A.; Wopereis, M.C.S. Increasing rice productivity through improved nutrient use in Africa. In Realizing Africa's Rice Promise; Wopereis, M.C.S., Johnson, D.E., Ahmadi, N., Tollens, E., Jalloh, A., Eds.; CABI: Wallingford, UK, 2013; pp. 250-264. ISBN 978-1-84593-812-3.

15. Balasubramanian, V.; Sie, M.; Hijmans, R.J.; Otsuka, K. Increasing Rice Production in Sub-Saharan Africa: Challenges and Opportunities. In Advances in Agronomy; Sparks, D.L., Ed.; Academic Press: Cambridge, MA, USA, 2007; Volume 94, pp. 55-133.

16. Becker, M.; Johnson, D.E. Improved water control and crop management effects on lowland rice productivity in West Africa. Nutr. Cycl. Agroecosyst. 2001, 59, 119-127. [CrossRef]

17. Öpik, M.; Moora, M.; Liira, J.; Zobel, M. Composition of root-colonizing arbuscular mycorrhizal fungal communities in different ecosystems around the globe. J. Ecol. 2006, 94, 778-790. [CrossRef]

18. Jacoby, R.; Peukert, M.; Succurro, A.; Koprivova, A.; Kopriva, S. The Role of Soil Microorganisms in Plant Mineral Nutrition-Current Knowledge and Future Directions. Front. Plant Sci. 2017, 8, 1617. [CrossRef]

19. Schnitzer, S.A.; Klironomos, J.; HilleRisLambers, J.; Kinkel, L.L.; Reich, P.B.; Xiao, K.; Rillig, M.C.; Sikes, B.A.; Callaway, R.M.; Mangan, S.A.; et al. Soil microbes drive the classic plant diversity-productivity pattern. Ecology 2011, 92, 296-303. [CrossRef]

20. Aislabie, J.; Deslippe, J.R. Soil microbes and their contribution to soil services. In Ecosystem services in New Zealand-Conditions and Trends; Dymond, J.R., Ed.; Manaaki Whenua Press: Lincoln, New Zealand, 2013; pp. 143-161.

21. Harman, G.E.; Uphoff, N. Symbiotic Root-Endophytic Soil Microbes Improve Crop Productivity and Provide Environmental Benefits. Scientifica 2019, 2019, 9106395. [CrossRef]

22. De Beenhouwer, M.; Van Geel, M.; Ceulemans, T.; Muleta, D.; Lievens, B.; Honnay, O. Changing soil characteristics alter the arbuscular mycorrhizal fungi communities of Arabica coffee (Coffea arabica) in Ethiopia across a management intensity gradient. Soil Biol. Biochem. 2015, 91, 133-139. [CrossRef]

23. Urcoviche, R.C.; Castelli, M.; Gimenes, R.M.T.; Alberton, O. Spore density and diversity of arbuscular mycorrhizal fungi in medicinal and seasoning plants. Afr. J. Agric. Res. 2014, 9, 1244-1251.

24. Balestrini, R.; Lumini, E. Focus on mycorrhizal symbioses. Appl. Soil Ecol. 2018, 123, 299-304. [CrossRef]

25. Smith, S.E.; Read, D.J. Mycorrhizal Symbiosis, 3rd ed.; Elsevier: Amsterdam, The Netherlands, 2008; ISBN 978-0-12-370526-6.

26. Choi, J.; Summers, W.; Paszkowski, U. Mechanisms Underlying Establishment of Arbuscular Mycorrhizal Symbioses. Annu. Rev. Phytopathol. 2018, 56, 135-160. [CrossRef] [PubMed]

27. Smith, S.E.; Facelli, E.; Pope, S.; Andrew Smith, F. Plant performance in stressful environments: Interpreting new and established knowledge of the roles of arbuscular mycorrhizas. Plant Soil 2010, 326, 3-20. [CrossRef]

28. Impact of Arbuscular Mycorrhizas on Sustainable Agriculture and Natural Ecosystems; Gianiazzi, S.; Schüepp, H. (Eds.) Advances in Life Sciences: Birkhäuser Basel, Switzerland, 1994; ISBN 978-3-0348-9654-2.

29. Wilson, G.W.T.; Rice, C.W.; Rillig, M.C.; Springer, A.; Hartnett, D.C. Soil aggregation and carbon sequestration are tightly correlated with the abundance of arbuscular mycorrhizal fungi: Results from long-term field experiments. Ecol. Lett. 2009, 12, 452-461. [CrossRef]

30. Camenzind, T.; Hammer, E.C.; Lehmann, J.; Solomon, D.; Horn, S.; Rillig, M.C.; Hempel, S. Arbuscular mycorrhizal fungal and soil microbial communities in African Dark Earths. FEMS Microbiol. Ecol. 2018, 94, fiy033. [CrossRef]

31. Wang, B.; Qiu, Y.-L. Phylogenetic distribution and evolution of mycorrhizas in land plants. Mycorrhiza 2006, 16, 299-363. [CrossRef]

32. Blanke, V.; Renker, C.; Wagner, M.; Füllner, K.; Held, M.; Kuhn, A.J.; Buscot, F. Nitrogen supply affects arbuscular mycorrhizal colonization of Artemisia vulgaris in a phosphate-polluted field site. New Phytol. 2005, 166, 981-992. [CrossRef]

33. Säle, V.; Aguilera, P.; Laczko, E.; Mäder, P.; Berner, A.; Zihlmann, U.; van der Heijden, M.G.A.; Oehl, F. Impact of conservation tillage and organic farming on the diversity of arbuscular mycorrhizal fungi. Soil Biol. Biochem. 2015, 84, 38-52. [CrossRef]

34. Smith, S.E.; Smith, F.A.; Jakobsen, I. Functional diversity in arbuscular mycorrhizal (AM) symbioses: The contribution of the mycorrhizal P uptake pathway is not correlated with mycorrhizal responses in growth or total P uptake. New Phytol. 2004, 162, 511-524. [CrossRef] 
35. Torrecillas, E.; Alguacil, M.M.; Roldán, A. Host Preferences of Arbuscular Mycorrhizal Fungi Colonizing Annual Herbaceous Plant Species in Semiarid Mediterranean Prairies. Appl. Environ. Microbiol. 2012, 78, 6180-6186. [CrossRef]

36. Xu, X.; Chen, C.; Zhang, Z.; Sun, Z.; Chen, Y.; Jiang, J.; Shen, Z. The influence of environmental factors on communities of arbuscular mycorrhizal fungi associated with Chenopodium ambrosioides revealed by MiSeq sequencing investigation. Sci. Rep. 2017, 7, 45134. [CrossRef] [PubMed]

37. Davison, J.; Öpik, M.; Zobel, M.; Vasar, M.; Metsis, M.; Moora, M. Communities of Arbuscular Mycorrhizal Fungi Detected in Forest Soil Are Spatially Heterogeneous but Do Not Vary throughout the Growing Season. PLOS ONE 2012, 7, e41938. [CrossRef] [PubMed]

38. Wang, P.; Wang, Y. Community Analysis of Arbuscular Mycorrhizal Fungi in Roots of Poncirus trifoliata and Citrus reticulata Based on SSU rDNA. Sci. World J. 2014, 2014, 1-8.

39. Lee, E.-H.; Eo, J.-K.; Ka, K.-H.; Eom, A.-H. Diversity of Arbuscular Mycorrhizal Fungi and Their Roles in Ecosystems. Mycobiology 2013, 41, 121-125. [CrossRef]

40. Öpik, M.; Vanatoa, A.; Vanatoa, E.; Moora, M.; Davison, J.; Kalwij, J.M.; Reier, Ü.; Zobel, M. The online database MaarjAM reveals global and ecosystemic distribution patterns in arbuscular mycorrhizal fungi (Glomeromycota). New Phytol. 2010, 188, 223-241. [CrossRef]

41. Buri, M.M.; Iassaka, R.N.; Fujii, H.; Wakatsuki, T. Comparison of soil nutrient status of some rice growing environments in the major agro-ecological zones of Ghana. J. Food Agric. Environ. 2010, 5, 384-388.

42. del Mar Alguacil, M.; Torres, M.P.; Montesinos-Navarro, A.; Roldán, A. Soil Characteristics Driving Arbuscular Mycorrhizal Fungal Communities in Semiarid Mediterranean Soils. Appl. Environ. Microbiol. 2016, 82, 3348-3356. [CrossRef]

43. Chen, X.-W.; Wu, F.-Y.; Li, H.; Chan, W.-F.; Wu, S.-C.; Wong, M.-H. Mycorrhizal colonization status of lowland rice (Oryza sativa L.) in the southeastern region of China. Environ. Sci. Pollut. Res. 2017, 24, 5268-5276. [CrossRef]

44. Lumini, E.; Vallino, M.; Alguacil, M.M.; Romani, M.; Bianciotto, V. Different farming and water regimes in Italian rice fields affect arbuscular mycorrhizal fungal soil communities. Ecol. Appl. 2011, 21, 1696-1707. [CrossRef]

45. Barber, N.A.; Kiers, E.T.; Theis, N.; Hazzard, R.V.; Adler, L.S. Linking agricultural practices, mycorrhizal fungi, and traits mediating plant-insect interactions. Ecol. Appl. 2013, 23, 1519-1530. [CrossRef]

46. Fromin, N.; Hamelin, J.; Tarnawski, S.; Roesti, D.; Jourdain-Miserez, K.; Forestier, N.; Teyssier-Cuvelle, S.; Gillet, F.; Aragno, M.; Rossi, P. Statistical analysis of denaturing gel electrophoresis (DGE) fingerprinting patterns. Environ. Microbiol. 2002, 4, 634-643. [CrossRef] [PubMed]

47. Vallino, M.; Fiorilli, V.; Bonfante, P. Rice flooding negatively impacts root branching and arbuscular mycorrhizal colonization, but not fungal viability. Plant Cell Environ. 2014, 37, 557-572. [CrossRef] [PubMed]

48. Lumini, E.; Orgiazzi, A.; Borriello, R.; Bonfante, P.; Bianciotto, V. Disclosing arbuscular mycorrhizal fungal biodiversity in soil through a land-use gradient using a pyrosequencing approach. Environ. Microbiol. 2010, 12, 2165-2179. [CrossRef] [PubMed]

49. Wang, Y.; Li, T.; Li, Y.; Björn, L.O.; Rosendahl, S.; Olsson, P.A.; Li, S.; Fu, X. Community Dynamics of Arbuscular Mycorrhizal Fungi in High-Input and Intensively Irrigated Rice Cultivation Systems. Appl. Environ. Microbiol. 2015, 81, 2958-2965. [CrossRef]

50. Watanarojanaporn, N.; Boonkerd, N.; Tittabutr, P.; Longtonglang, A.; Young, J.P.W.; Teaumroong, N. Effect of Rice Cultivation Systems on Indigenous Arbuscular Mycorrhizal Fungal Community Structure. Microb. Environ. 2013, 28, 316-324. [CrossRef]

51. Dipankar, M.; Mukund, V.; Jayanta, S. Colonization of upland rice by native VAM under rainfed mono-cropped ecosystem. In Recent Advances in Phytopath; M D Publ. Ltd.: New Delhi, India, 1995.

52. Bernaola, L.; Cange, G.; Way, M.O.; Gore, J.; Hardke, J.; Stout, M. Natural Colonization of Rice by Arbuscular Mycorrhizal Fungi in Different Production Areas. Rice Sci. 2018, 25, 169-174. [CrossRef]

53. Van Geel, M.; Verbruggen, E.; De Beenhouwer, M.; van Rennes, G.; Lievens, B.; Honnay, O. High soil phosphorus levels overrule the potential benefits of organic farming on arbuscular mycorrhizal diversity in northern vineyards. Agric. Ecosyst. Environ. 2017, 248, 144-152. [CrossRef]

54. Vályi, K.; Rillig, M.C.; Hempel, S. Land-use intensity and host plant identity interactively shape communities of arbuscular mycorrhizal fungi in roots of grassland plants. New Phytol. 2015, 205, 1577-1586. [CrossRef] 
55. Tchabi, A.; Coyne, D.; Hountondji, F.; Lawouin, L.; Wiemken, A.; Oehl, F. Arbuscular mycorrhizal fungal communities in Sub-Saharan Savannas of Benin, West Africa, as affected by agricultural land use intensity and ecological zone. Mycorrhiza 2008, 18, 181-195. [CrossRef]

56. Santos, J.C.; Finlay, R.D.; Tehler, A. Molecular analysis of arbuscular mycorrhizal fungi colonising a semi-natural grassland along a fertilisation gradient. New Phytol. 2006, 172, 159-168. [CrossRef]

57. Casazza, G.; Lumini, E.; Ercole, E.; Dovana, F.; Guerrina, M.; Arnulfo, A.; Minuto, L.; Fusconi, A.; Mucciarelli, M. The abundance and diversity of arbuscular mycorrhizal fungi are linked to the soil chemistry of screes and to slope in the Alpic paleo-endemic Berardia subacaulis. PLoS ONE 2017, 12, e0171866. [CrossRef] [PubMed]

58. Manoharan, L.; Rosenstock, N.P.; Williams, A.; Hedlund, K. Agricultural management practices influence AMF diversity and community composition with cascading effects on plant productivity. Appl. Soil Ecol. 2017, 115, 53-59. [CrossRef]

59. Hazard, C.; Gosling, P.; Van Der Gast, C.J.; Mitchell, D.T.; Doohan, F.M.; Bending, G.D. The role of local environment and geographical distance in determining community composition of arbuscular mycorrhizal fungi at the landscape scale. ISME J. 2013, 7, 498-508. [CrossRef] [PubMed]

60. Jansa, J.; Erb, A.; Oberholzer, H.-R.; Šmilauer, P.; Egli, S. Soil and geography are more important determinants of indigenous arbuscular mycorrhizal communities than management practices in Swiss agricultural soils. Mol. Ecol. 2014, 23, 2118-2135. [CrossRef] [PubMed]

61. Redecker, D.; Schüßler, A.; Stockinger, H.; Stürmer, S.L.; Morton, J.B.; Walker, C. An evidence-based consensus for the classification of arbuscular mycorrhizal fungi (Glomeromycota). Mycorrhiza 2013, 23, 515-531. [CrossRef]

62. Nakagawa, T.; Imaizumi-Anraku, H. Rice arbuscular mycorrhiza as a tool to study the molecular mechanisms of fungal symbiosis and a potential target to increase productivity. Rice 2015, 8, 32. [CrossRef]

63. Shah, M.P. Evaluation and Analysis of Bacterial Communities from Different Waste Water Treatment Plants by Denaturing Gradient Gel Electrophoresis with Group Specific 16s rRNA. Int. J. Environ. Bioremed. Biodegrad. 2014, 2, 100-111.

64. Schüßler, A.; Walker, C. The Glomermycota: A Species List with New Families and New Genera. Available online: http://www.amf-phylogeny.com/species_infos/higher_taxa/funneliformis_ claroideoglomus_rhizophagus_redeckera.pdf (accessed on 12 September 2019).

65. Hijri, I.; Sýkorová, Z.; Oehl, F.; Ineichen, K.; Mäder, P.; Wiemken, A.; Redecker, D. Communities of arbuscular mycorrhizal fungi in arable soils are not necessarily low in diversity. Mol. Ecol. 2006, 15, 2277-2289. [CrossRef]

66. Daniell, T.J.; Husband, R.; Fitter, A.H.; Young, J.P.W. Molecular diversity of arbuscular mycorrhizal fungi colonising arable crops. FEMS Microbiol. Ecol. 2001, 36, 203-209. [CrossRef]

67. Wang, C.; Gu, Z.; Cui, H.; Zhu, H.; Fu, S.; Yao, Q. Differences in Arbuscular Mycorrhizal Fungal Community Composition in Soils of Three Land Use Types in Subtropical Hilly Area of Southern China. PLoS ONE 2015, 10, e0130983. [CrossRef]

68. Hempel, S.; Renker, C.; Buscot, F. Differences in the species composition of arbuscular mycorrhizal fungi in spore, root and soil communities in a grassland ecosystem. Environ. Microbiol. 2007, 9, 1930-1938. [CrossRef] [PubMed]

69. Varela-Cervero, S.; Vasar, M.; Davison, J.; Barea, J.M.; Öpik, M.; Azcón-Aguilar, C. The composition of arbuscular mycorrhizal fungal communities differs among the roots, spores and extraradical mycelia associated with five Mediterranean plant species. Environ. Microbiol. 2015, 17, 2882-2895. [CrossRef] [PubMed]

70. Finlay, R.D. Ecological aspects of mycorrhizal symbiosis: With special emphasis on the functional diversity of interactions involving the extraradical mycelium. J. Exp. Bot. 2008, 59, 1115-1126. [CrossRef]

71. Hu, Y.; Rillig, M.C.; Xiang, D.; Hao, Z.; Chen, B. Changes of AM Fungal Abundance along Environmental Gradients in the Arid and Semi-Arid Grasslands of Northern China. PLoS ONE 2013, 8, e57593. [CrossRef] [PubMed]

72. Rodríguez-Echeverría, S.; Teixeira, H.; Correia, M.; Timóteo, S.; Heleno, R.; Öpik, M.; Moora, M. Arbuscular mycorrhizal fungi communities from tropical Africa reveal strong ecological structure. New Phytol. 2017, 213, 380-390. [CrossRef] [PubMed] 
73. Alguacil, M.M.; Torres, M.P.; Torrecillas, E.; Díaz, G.; Roldán, A. Plant type differently promote the arbuscular mycorrhizal fungi biodiversity in the rhizosphere after revegetation of a degraded, semiarid land. Soil Biol. Biochem. 2011, 43, 167-173. [CrossRef]

74. Li, L.-F.; Li, T.; Zhang, Y.; Zhao, Z.-W. Molecular diversity of arbuscular mycorrhizal fungi and their distribution patterns related to host-plants and habitats in a hot and arid ecosystem, southwest China. FEMS Microbiol. Ecol. 2010, 71, 418-427. [CrossRef]

75. Schüßler, A.; Krüger, M.; Walker, C. Revealing Natural Relationships among Arbuscular Mycorrhizal Fungi: Culture Line BEG47 Represents Diversispora epigaea, Not Glomus versiforme. PLoS ONE 2011, 6, e23333. [CrossRef]

76. Rousk, J.; Bååth, E.; Brookes, P.C.; Lauber, C.L.; Lozupone, C.; Caporaso, J.G.; Knight, R.; Fierer, N. Soil bacterial and fungal communities across a pH gradient in an arable soil. ISME J. 2010, 4, 1340-1351. [CrossRef]

77. van der Heijden, M.G.A.; Wagg, C. Soil microbial diversity and agro-ecosystem functioning. Plant Soil 2013, 363, 1-5. [CrossRef]

78. Deepika, S.; Kothamasi, D. Soil moisture-A regulator of arbuscular mycorrhizal fungal community assembly and symbiotic phosphorus uptake. Mycorrhiza 2015, 25, 67-75. [CrossRef] [PubMed]

79. Bever, J.D.; Schultz, P.A.; Pringle, A.; Morton, J.B. Arbuscular Mycorrhizal Fungi: More Diverse than Meets the Eye, and the Ecological Tale of Why. BioScience 2001, 51, 923. [CrossRef]

80. Xiang, D.; Verbruggen, E.; Hu, Y.; Veresoglou, S.D.; Rillig, M.C.; Zhou, W.; Xu, T.; Li, H.; Hao, Z.; Chen, Y.; et al. Land use influences arbuscular mycorrhizal fungal communities in the farming-pastoral ecotone of northern China. New Phytol. 2014, 204, 968-978. [CrossRef] [PubMed]

81. Yoshimura, Y.; Ido, A.; Iwase, K.; Matsumoto, T.; Yamato, M. Communities of Arbuscular Mycorrhizal Fungi in the Roots of Pyrus pyrifolia var. culta (Japanese Pear) in Orchards with Variable Amounts of Soil-Available Phosphorus. Microbes Environ. 2013, 28, 105-111. [CrossRef] [PubMed]

82. Codjoe, S.N.A.; Bilsborrow, R.E. Population and agriculture in the dry and derived savannah zones of Ghana. Popul. Environ. 2011, 33, 80-107. [CrossRef]

83. Food and Agriculture Organization of the United Nations (FAO). World Reference base for Soil Resources 2014, International Soil classification System for Naming Soils and Creating Legends for Soil Maps. Available online: http://www.fao.org/soils-portal/soil-survey/soil-classification/world-reference-base/en/pdf (accessed on 15 July 2018).

84. Tropical Soil Biology and Fertility: A Handbook of Methods, 2nd ed.; Anderson, J.M.; Ingram, J.S.I. (Eds.) International Union of Biological Sciences: Paris, France; International Society of Soil Science: Vienna, Austria; CAB International: Wallingford, UK, 1993; ISBN 978-0-85198-821-4.

85. Truog, E. The Determination of the Readily Available Phosphorus of Soils 1. Agron. J. 1930, 22, 874-882. [CrossRef]

86. Parsons, T.R.; Maita, Y.; Lalli, C.M. Manual of Chemical and Biological Methods for Seawater Analysis; Pergamon Press: Oxford, UK, 1984; ISBN 978-0-08-030287-4.

87. Schollenberger, C.J.; Simon, R.H. Determination of Exchange Capacity and Exchangeable bases in soil-Ammonium acetate method. Soil Sci. 1945, 59, 13-24. [CrossRef]

88. Phillips, J.M.; Hayman, D.S. Improved procedures for clearing roots and staining parasitic and vesicular-arbuscular mycorrhizal fungi for rapid assessment of infection. Trans. Br. Mycol. Soc. 1970, 55, 158-160. [CrossRef]

89. Kouichi, S.; Yoshihisa, S.; Masanori, S.; Kazuo, S. A new primer for discrimination of arbuscular mycorrhizal fungi with polymerase chain reaction-denature gradient gel electrophoresis. Grassl. Sci. 2005, 51, 179-181.

90. Muyzer, G.; de Waal, E.C.; Uitterlinden, A.G. Profiling of complex microbial populations by denaturing gradient gel electrophoresis analysis of polymerase chain reaction-amplified genes coding for 16S rRNA. Appl. Environ. Microbiol. 1993, 59, 695-700. [CrossRef]

91. Kumar, S.; Stecher, G.; Li, M.; Knyaz, C.; Tamura, K. MEGA X: Molecular Evolutionary Genetics Analysis across Computing Platforms. Mol. Biol. Evol. 2018, 35, 1547-1549. [CrossRef] [PubMed]

92. Caporaso, J.G.; Kuczynski, J.; Stombaugh, J.; Bittinger, K.; Bushman, F.D.; Costello, E.K.; Fierer, N.; Peña, A.G.; Goodrich, J.K.; Gordon, J.I.; et al. QIIME allows analysis of high-throughput community sequencing data. Nat. Methods 2010, 7, 335-336. [CrossRef] [PubMed] 
93. Lee, C.G.; Iida, T.; Uwagaki, Y.; Otani, Y.; Nakaho, K.; Ohkuma, M. Comparison of Prokaryotic and Eukaryotic Communities in Soil Samples with and without Tomato Bacterial Wilt Collected from Different Fields. Microbes Environ. 2017, 32, 376-385. [CrossRef] [PubMed]

94. Gomes, E.A.; Oliveira, C.A.; Lana, U.G.P.; Noda, R.W.; Marriel, I.E.; Souza, F.A. de Arbuscular Mycorrhizal Fungal Communities in the Roots of Maize Lines Contrasting for Al Tolerance Grown in Limed and Non-Limed Brazilian Oxisoil. J. Microbiol. Biotechnol. 2015, 25, 978-987. [CrossRef]

(C) 2020 by the authors. Licensee MDPI, Basel, Switzerland. This article is an open access article distributed under the terms and conditions of the Creative Commons Attribution (CC BY) license (http://creativecommons.org/licenses/by/4.0/). 